\title{
Dossiê música e cena do Théâtre du Soleil
}

As comadres de Ariane Mnouchkine

\section{As Comadres: Ariane Mnouchkine dirige no Brasil}

Julia Carrera

É doutoranda no Programa de Pós-Graduação em Artes da Cena da UNIRIO, na linha de História e Historiografia do Teatro e das Artes onde pesquisa a filmografia do Théâtre du Soleil (O Cinema no Théâtre du Soleil: memória, estética e paixão - projeto em andamento; orientação da Prof. Ana Bulhões). É mestre em Artes da Cena pela Escola de Comunicação da UFRJ, na Direção Teatral (pesquisa com ênfase em teatro e cinema). É atriz, produtora, professora e diretora de teatro com vários espetáculos realizados ao longo dos últimos vinte anos, no eixo Rio-São Paulo. É co-fundadora da AURORA - Polo de Pesquisa Teatral, voltado aos estudos sobre o Théâtre du Soleil em língua portuguesa. 


\section{Resumo}

O artigo trata sobre alguns aspectos do encontro entre os teatros do Brasil, da França e do Canadá por ocasião da montagem de As Comadres, adaptação de Les Belles-Soeurs de Michel Tremblay (1965), libreto e encenação de René Richard Cyr (2010), música de Daniel Bélanger (2010), direção musical de Wladimir Pinheiro e supervisão artística de Ariane Mnouchkine. O espetáculo estreou em 27 de março de 2019 no Festival de Curitiba. Fez apresentações dias 27 e 28 de março, no Teatro Guairinha (Rua 15 de Novembro, 971, Curitiba), de 11 de abril a 02 de junho no Teatro Sesc Ginástico (Avenida Graça Aranha, 187, Rio de Janeiro) e de 05 a 28 de julho no Teatro Anchieta do Sesc Consolação (Rua Doutor Vila Nova, 245, São Paulo).

Palavras-chave: Les Belles-Soeurs, Mnouchkine, Brasil, Joual, Songs brechtianas. 
“(...) Para elas, a impotência não é um problema, é uma realidade da qual elas sofrem e da qual nunca tomam consciência. Nunca, porque o 'joual' - que é uma língua empobrecida, sem poder de sair da realidade imediata - impede qualquer tomada de consciência. 'A gente é baratinha!', para elas é a constatação de uma realidade irremediável. Não se sai desse gueto aqui.

Tremblay não sente pena de si mesmo, ele nos diz brutalmente: Olhem bem! É assim! É tão ruim quanto isso! Em 'As Comadres' só há uma reação possível: 'Não! Eu não aceito isso nem para mim nem para ninguém!'. Evidentemente pode ser que nem todo mundo reaja dessa forma a 'As Comadres'. Um coisa embora é certa: ninguém sairá da peça de consciência leve." (GERMAINE: 1968, p. 4)

Revista do Laboratório de Dramaturgia | LADI - UnB Vol. 14, Ano 5 | Dossiê música e cena do Théâtre du Soleil 
Em junho de 2018, Ariane Mnouchkine e Juliana Carneiro da Cunha, diretora e atriz do lendário Théâtre du Soleil respectivamente, chegaram ao Rio de Janeiro para estudos e montagem de um espetáculo canadense que trata da condição da mulher nos subúrbios das grandes cidades com uma equipe de artistas brasileiras, um "Teatro Solidário", em suas palavras. O que um projeto como esse representa dentro de um contexto de ascensão da terceira onda do feminismo no país em paralelo ao desmonte das políticas públicas, sociais e culturais, a nível nacional? "As Comadres" é um projeto, em plena realização, que inclui a montagem do espetáculo musical "Les Belles-Soeurs" (título original canadense) e a realização de um documentário que segue de perto este momento único de encontro entre culturas através do teatro, ao mesmo tempo que propõe uma reflexão sobre os impactos desta experiência no contexto cultural, político e social do atual momento brasileiro. O filme acompanhou todo o processo de criação do espetáculo, desde as primeiras reuniões em 2018 até a repercussão da peça junto ao público, que estreou em março de 2019 no Festival de Curitiba, tornando-se já uma referência importante no gênero dos filmes de teatro, além de um importante documento testemunhal sobre a passagem de algumas das maiores artistas do teatro ocidental pelo teatro brasileiro. Já o espetáculo, trata-se de uma versão brasileira da peça que marcou a transição do teatro no Canadá, do chamado 'canadense-francês' para o "quebequense: "Les Belles-Soeurs", de Michel Tremblay, incluída na lista das 49 peças emblemáticas a fazerem parte da biblioteca ideal do teatro (desde as origens até os dias atuais) pela revista francesa "Lire" em 1987, que ganhou versão musical de René Richard Cyr em 2010, revivendo a potência transformadora da obra.

Na década de sessenta, o Quebec viveu a denominada "Revolução Tranquila", quando ocorreu uma série de transformações sociais e políticas que constituíram a região que se conhece hoje. Com a morte do Primeiro Ministro Maurice Duplessis, o período de subserviência da população quebequense se encerrou, dando lugar a reformas pautadas por uma renovação da consciência coletiva enquanto nação quebequense, acompanhada por um movimento literário e artístico que deu voz a esse movimento, conforme afirma Marcel Rioux, importante nome da sociologia e teoria crítica do Canadá. Segundo o autor, a oposição ideológica anterior à 1960 configurava uma "contestação de recuperação", que preenchia a lacuna entre a cultura quebequense (ideias, valores, simbolos e atitudes) e a sociedade quebequense (urbanização, tecnologia, economia), onde germinava um desejo crescente da população de tomar o poder sobre a economia e a política do país e sair dos domínios socioculturais estrangeiros. Neste contexto, o então jovem autor, Michel Tremblay, escreveu a peça "Les Belles-Soeurs", na qual se sobrepõem algumas questões que figuravam na pauta das transformações ocorridas na dita "Revolução Tranquila".

Em primeiro lugar, essa foi a primeira peça totalmente escrita em 'joual', o dialeto popular franco-canadense marcado por lacunas fonéticas e lexicais e 
pelo anglicismo. Com isso ele inclui a língua no alto círculo da dramaturgia ocidental e cria um marco no teatro canadense, dando voz (literalmente) a todo um segmento da população até então invisibilizado em sua característica primordial, a língua. Através da língua se revelou também um novo realismo no teatro quebequense, em que ganharam a cena quinze mutheres de meia idade cujas vidas são reduzidas ao infindável trabalho doméstico, ao cuidado com os filhos, aos caprichos dos maridos (que ficam na fronteira entre os deveres do matrimônio e o abuso sexual), à repressão da religião católica versus a liberalidade das danceterias de fama duvidosa.

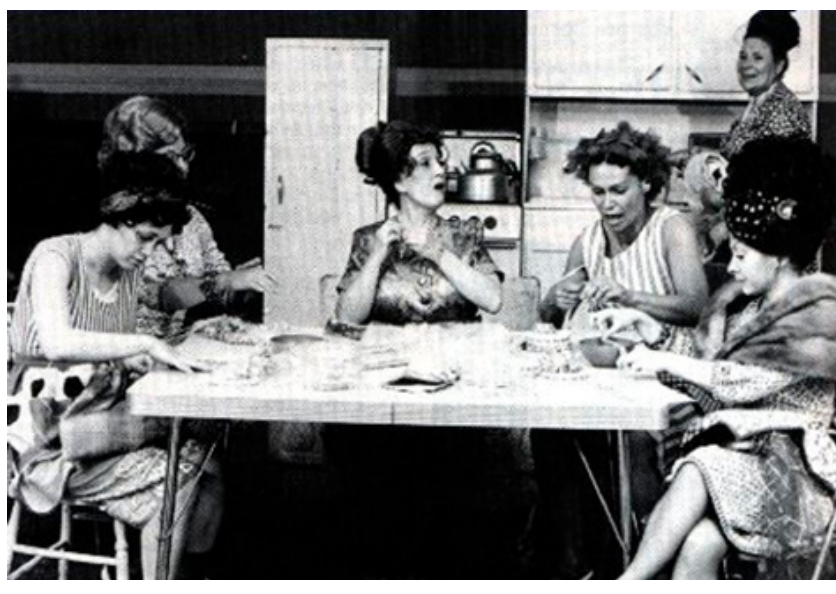

Figura 1: Elenco original de Les BellesSoeurs no Théâtre du Rideau Vert em Montreal, 1968.

Surgiu em cena também a transição entre um materialismo modesto e o anseio materialista como fonte de realização pessoal real. Quando, em um sorteio, a protagonista, Germana, ganha um milhão de selos a serem colados em catálogos e trocados por todos os prêmios em uma grande loja de departamento, ela se vê, pela primeira vez, diante da felicidade, irá 'possuir' tudo aquilo que uma mulher almeja: "A casa vai ficar novinha, fogão, mobília e jogo de cozinha, a geladeira azul e um belo faqueiro daqueles bom, já escolhi, eu vou levar", ela canta na música que abre o espetáculo, enquanto o coro brada: "Vai ser tudo dela, tudinho dela, Grátis". Essa felicidade que cai em seus colos como uma benesse por seu uma boa esposa e mãe atrai o olhar das convidadas para a noite de 'colação de selos': todas as comadres, irmãs, vizinhas, cunhadas, a filha e suas amigas, enquanto colam os selos se perguntam 'Por que ela e não eu?', levando ao catártico momento da peça, onde todas estraçalham as caixas de selos, roubando furiosamente, diante de uma Germana atônita mas não transformada.

Porém não só Germana não se modifica, como nenhuma daquelas mulheres o faz. Durante a peça, cada uma tem o seu momento solo, onde desfiam as mazelas e pequenezas da vida de cada uma (e de todas as mulheres, em todas as épocas). Pelos títulos das músicas, os dilemas se evidenciam: Vidinha Escrota, As Bodas (da filha), Que Vergonha, Meu Vendedor de Escovas (Vassoreiro), Tenho Cara de Quem Já Se Deu Bem, A Morte Não Tarda, Mulher Sem Luz, Cabaré, Desgraça de Johnny, O Bingo, Maldito Cú e Voltarei Pela Porta da Frente. Mesmo Pietra, a irmã caçula que, quando jovem, deixa a família para uma vida mais liberal, acaba retornando à casa da irmã, com a notícia dos selos, mas principalmente por ter sido largada pelo namorado (e, depois, cafetão), já que não serve mais para a vida dos cabarés. Todas aquelas muIheres estão fadadas aos seus destinos não por falta de força, mas por falta de consciência de sua força. 
A peça dialogava ainda com outras questões na pauta da "Revolução Tranquila" que estava em curso. Se na vida dos quebequenses se podia sentir a secularização da sociedade, com a religião católica perdendo poder de forma efetiva e rápida, em As Comadres a religião é extremamente presente, personificada em uma dupla de personagens em especial. Angelina e Romilda, duas carolas que vivem juntas e cujo comportamento em nada se difere de um casal, tem a relação ameaçada quando a primeira descobre que a segunda vem frequentando o cabaré às escondidas. Mas a crise é superada quando essa se desculpa e promete voltar a ser uma boa devota do 'Pai'. Em uma cena que antecede essa crise, todas as comadres munidas de seus terços, às seis horas em ponto, ajoelham-se na cozinha e rezam o Pai Nosso seguindo o padre que reza em latim pelo rádio. Ao que uma delas, Mariangela, se pergunta "O que mais Germana poderia pedir aos céus depois da benção que recebeu..."

Entra em cena também a questão do aborto, cujo debate sobre a legalização no Canadá viria em seguida, na esteira da criação de um ÉtatProvidence (Estado de Bem-Estar Social). A jovem Lisa, garçonete de uma lanchonete, lamenta-se de só vestir uniforme e confidencia à Pietra sua necessidade de encarar um aborto (ainda que doméstico), já que engravidou e o namorado sumiu, e porque ela realmente deseja ter uma vida diferente daquela da maioria das mulheres de lá: 'Eu vim ao mundo pela porta de trás, mas vou sair pela porta da frente. Eu cometi um erro mas vou reparar, nada vai me impedir, ninguém pode me atrapalhar', Lisa canta, seguida pelo coro de

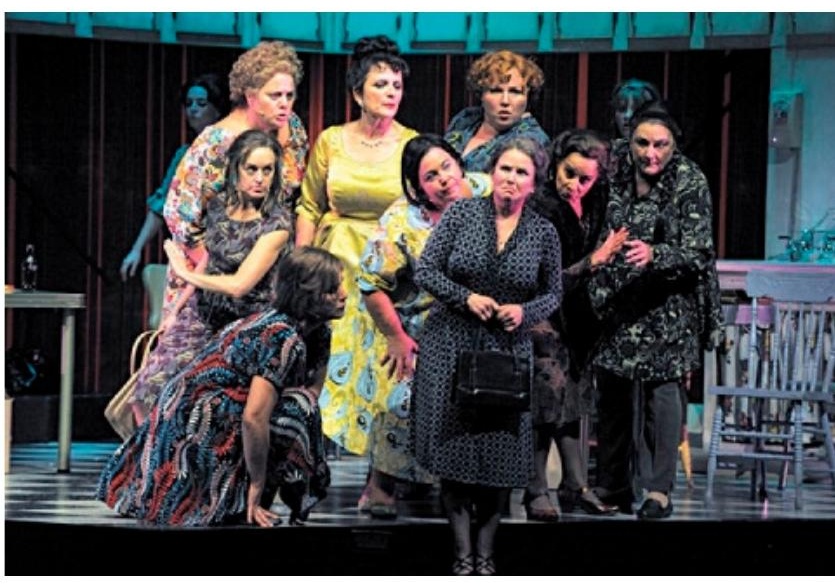

Figura 2: Foto de Valérie Remise da versão musical canadense em 2013. mulheres em uníssono. Pietra, então, encaminha a jovem a um médico que faz o procedimento com toda a segurança, em muito mais mulheres do que se gostaria de imaginar, como ela explica'.

Alguns espetáculos canadenses da época continham a ressonância com o momento político do país, mas, afirmam teóricos como Jean-Claude Germaine, a maioria deles não iam além do discurso panfletário de seus autores, através das palavras de seus personagens. A maestria de Tremblay, também jovem autor na época em que escreveu a peça, reside, principalmente, em como conseguiu criar personagens multifacetados e realistas, a ponto de cruzar fronteiras e culturas. As muIheres de Tremblay habitam a periferia de uma metrópole no Quebec da década de sessenta, mas poderiam viver na periferia de qualquer grande cidade, a qualquer época. Uma das principais chaves de empatia que a peça dispõe são as construções dramatúrgicas da comédia popular clássica (com efeitos cômicos impagáveis, ouvimos os ecos de Moliére) e a capacidade de rir de si próprias que todas as personagens apresentam. As Comadres, assim, arregimentam fãs, por onde passam, desde a sua estreia, com uma tragicomicidade presente no universo feminino. 
Cômica pela sua estrutura, trágica pelo seu final nada feliz. As comadres, tomadas pela inveja, roubam os selos o mais que podem e seguem, cada uma para sua casa, certas de que também são merecedoras. As irmãs, Germana e Pietra, não conseguem se reconciliar. A filha, Linda, tenta consolar a mãe, que reprime a própria fragilidade até que a filha se afaste. E, por fim, na montagem de 1968 as mulheres se unem apenas para cantar o hino no final, enquanto que na versão musical de 2010, se unem para cantar a sorte perdida de Germana. Se na década de sessenta a ironia estava na falsa união de uma sociedade em ruínas (diante do novo que surgia), nos anos 2000 a questão nacionalista cede lugar ao materialismo consumista. Como diz Tremblay, a tragédia da peça não está na desilusão de Germana, mas na incapacidade de união daquelas mutheres. Naquele momento, a autonomia individual ainda vencia o cabo de força contra a solidariedade coletiva. Uma personagem chave da peça, uma senhora de noventa e quatro anos que é levada à casa de Germana por sua nora (e cuidadora) Tereza, que é louca, morde, rouba e é a primeira a entoar o hino da nação, representa o Canadá decrépito em meio àquelas mulheres almejando uma transição só alcançada por Lisa, a que quer sair pela porta da frente da vida, personificando a ideia de futuro que se construía. A peça é, portanto, um campo de batalha para todas as gerações de mulheres, igualmente massacradas pelas condições de vida dentro da sociedade que vivem, sem se darem conta de que o inimigo era exterior.

Passados cinquenta anos da sua estreia original, a peça ganha um novo e inusitado protagonismo no cenário do teatro mundial ao ganhar a direção de Ariane Mnouchkine, encenando, pela primeira vez, fora do Théâtre du Soleil. Enquanto sua companhia francesa seguia nos ensaios e posterior estreia do espetáculo Kanata, com direção de Robert Lepage, Mnouchkine aportou no Brasil para reunir uma equipe de artistas brasileiras em torno do texto, por sua consonância com os principais debates acerca da mulher no país, hoje. Entra em cena, então, a sororidade, a versão feminina para o termo "fraternidade", ultrapassando fronteiras culturais, atribuindo ao projeto um excelente lugar de reflexão no contexto da discussão sobre o feminismo no Brasil de uma forma geral, em especial na arte.

Linda Nochlin, no artigo "Porque não tem existido grandes mulheres artistas?", de 1988, afirma que assim como John Stuart Mills percebe a dominação masculina como uma de uma longa série de injustiças sociais que precisavam ser superadas para que se criasse uma ordem social verdadeiramente justa, então se poderia enxergar a dominação da subjetividade masculina branca como uma em uma série de distorções que precisariam ser corrigidas para atingir uma visão mais adequada e apurada de situações históricas. A autora segue desconstruindo tanto a pergunta que dá título ao trabalho quanto as respostas que surgem tanto do senso comum quanto de grupos que se acreditam feministas, chegando à questão que gira em torno do conceito de artista e das condições de criação propriamente ditos, o papel das instituições e a 
autoconsciência da artista feminina. Ao final ela considera que a artista deve conhecer seu passado histórico e tomar consciência das condições presentes, sem, no entanto, transformar as desigualdades em justificativas ou autopiedade. Ela propõe às artistas que se engajem na criação de ambientes ou instituições, corajosas o suficiente para assumir os riscos necessários e partir em busca de uma produção artística livre e desafiante para mulheres e homens, ultrapassando a ideia de gênero como uma questão a ser problematizada.

Essa provocação vem ao encontro não só dos princípios que nortearam a vida e a obra de Ariane Mnouchkine e do Théâtre du Soleil, sem que tenha havido a necessidade de uma reflexão teórica acerca da problematização do gênero. Na vivência do Théâtre du Soleil a questão de gênero foi superada ainda que a vigilância seja constante, todos os integrantes possuem os mesmos direitos e deveres, além de salários iguais, regras de ouro desde a criação da companhia na década de sessenta. A regra de igualdade é praticada mesmo àqueles que participam da vivência da companhia de forma sazonal, como quando foram acolhidos um sem número de imigrantes nos galpões do Soleil na década de noventa (homens dividiram afazeres domésticos com as mulheres contra a própria vontade ou hábito cultural) ou quando o Soleil fez surgir uma pequena companhia de teatro a partir de um estágio oferecido em Kabul, no Afeganistão (algumas poucas atrizes mulheres desconfiavam da liberdade que thes era autorizada ali por uma outra mulher na liderança de outros homens, que, entre outras coisas, incitava atores afegãos a usarem burcas pelas ruas da cidade destruída pela guerra civil - não só como exercício criativo mas como meio para uma verdadeira transformação social que reerguesse a economia local).

Em diversas entrevistas, Mnouchkine, sempre discreta porém autêntica em relação a sua vida particular, afirmou ter levado alguns bons anos de sua vida para perceber que algumas oportunidades seriam negadas para as mulheres. Encontrou amor, compreensão, confiança e incentivo no cerne de sua família e no círculo social em que conviveu até a juventude. Foi através dos relatos de outras mulheres, amigas, familiares, que começou a compreender as ditas questões do feminino e as várias maneiras de abordar soluções e apontar caminhos, sem que isso se tornasse uma bandeira política, do grupo ou particular. Indo ainda além, apesar de Mnouchkine lançar um olhar atento sobre o tema, ela nunca pôs em cheque seu lugar como chefe de trupe, encenadora ou cineasta, ou deixou que indivíduos ou instituições trouxessem a discussão de gênero como uma abordagem sobre sua figura ou sua obra.

Em relação às temáticas das obras criadas pela companhia não são poucas as referências à situação de opressão da mulher em diversas culturas, em diversas épocas. Através da marca do multiculturalismo impressa no repertório da trupe como um todo, a discussão da mulher e do feminino surge mesmo em espetáculos germinais como "A Cozinha" ou "1789", passando por "Os Átridas", "Tartuffo" nos anos noventa, e mesmo em espetáculos dos anos 2000, como 
"Le Dernier Caravansérail" e "Efêmeros". Através de cada criação a opressão da mulher (ou do feminino, como a personagem trans, Sandra, de "Efêmeros") é tratada sobre um determinado viés cultural ou histórico. E ao se debruçar sobre "As Comadres", não poderia ser diferente.

À frente do Théâtre du Soleil há 56 anos, Ariane Mnouchkine, uma das maiores diretoras do teatro ocidental no século XX, e Juliana Carneiro da Cunha, atriz franco-brasileira que lidera o elenco da companhia por 30 anos, são referência para aqueles que acompanham a vanguarda do teatro no mundo. Seus espetáculos e filmes, cujos temas envolvem pesquisas artísticas e políticas profundas com uma estética única, renovada a cada projeto, já passaram por todos os continentes, marcando profundamente as plateias que os assistiram. Em 2018, Juliana sentiu a necessidade de voltar aos palcos brasileiros em um projeto autoral. Repaginando uma parceria com esta autora, que data de 2002, quando conheci Juliana e o Théâtre du Soleil no estágio que foi oferecido pela companhia em Paris, nos pusemos à leitura de textos e discussões sobre meios de produção diante do desmantelamento das políticas de cultura já em curso no país e, principalmente, no Rio de Janeiro, que seria o palco principal da nossa aventura. Passados alguns meses e tentativas de associações frustradas, Juliana, em conversa com Ariane, chegou ao que tornou-se mais um capítulo de uma trajetória que mistura paixão pela arte e devoção ao trabalho coletivo da dupla. Decidiram trazer ao Rio de Janeiro "Les Belles-Soeurs", uma peça que uniria o antigo desejo de reflexão sobre a sociedade brasileira e uma forma teatral ainda inexplorada pela dupla, a comédia musical. Este tornou-se um projeto renovador e desafiante para as artistas, ao qual segui envolvida, somando-se ainda Fabianna Mello e Souza. À reboque surgiu a necessidade de um outro formato de produção, um híbrido entre a experiência de coletividade que o Théâtre du Soleil constrói há décadas na França e os métodos convencionais de produção teatral brasileiros, um "teatro solidário", para usar o termo cunhado por Mnouchkine para denominar nossa aventura. Desde os primeiros encontros em novembro de 2017, mais artistas, principalmente muIheres como Renata Sorrah, Simone Mazzer, Ana Achcar, Mina Quental, entre tantas outras, e nomes como o diretor musical Wladimir Pinheiro e o coordenador do Sesc Rio, André Gracindo, se aglutinaram ao projeto, movidos pelo desejo da criação artística coletiva e pela necessidade de resistência frente ao desmonte das políticas culturais pelo país nos últimos anos.

Ao todo somam hoje em torno de sessenta artistas trabalhando no projeto, dividindo entre si a responsabilidade de construir os meios para que cada etapa do projeto aconteça, posto que os ensaios começaram em março de 2018 na construção de um Model Buch (um termo alemão que designa um rascunho ou esboço de uma obra), a partir da encenação de René Richard Cyr. Tradução, locais de ensaio e preparação, cenários, figurinos, adereços, arranjos musicais, vídeos, filmagem, edição, elaboração de projetos para captação, enquadramento em leis de incentivo, entre muitas outras tarefas, são algumas das funções 


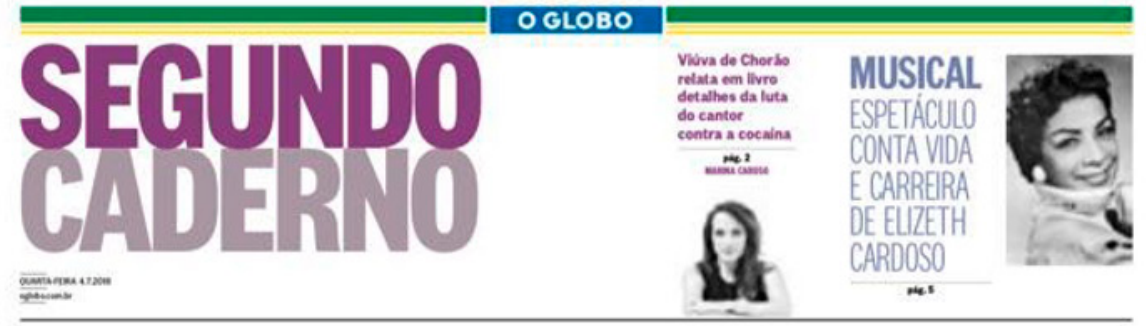

De passagem pelo Rio, a fundadora do Théâtre du Soleil, Ariane Mnouchkine, cria seu primeiro espetáculo para o Brasil, um musical com elenco inteiramente daqui e estreia prevista para 2019

\section{SELEÇÃO BRASILEIRA}

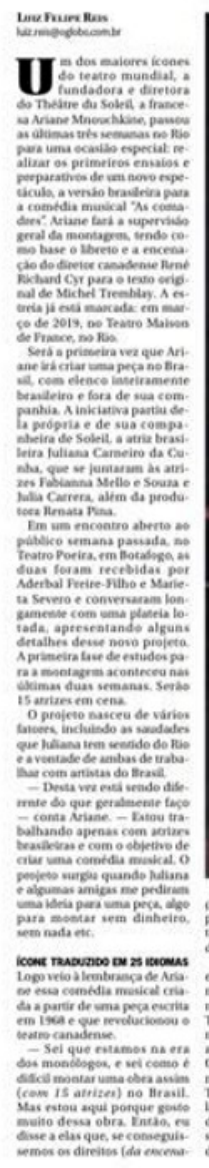

"Sei que estamos na era dos monólogos, e que é dificil

montar uma obra assim"

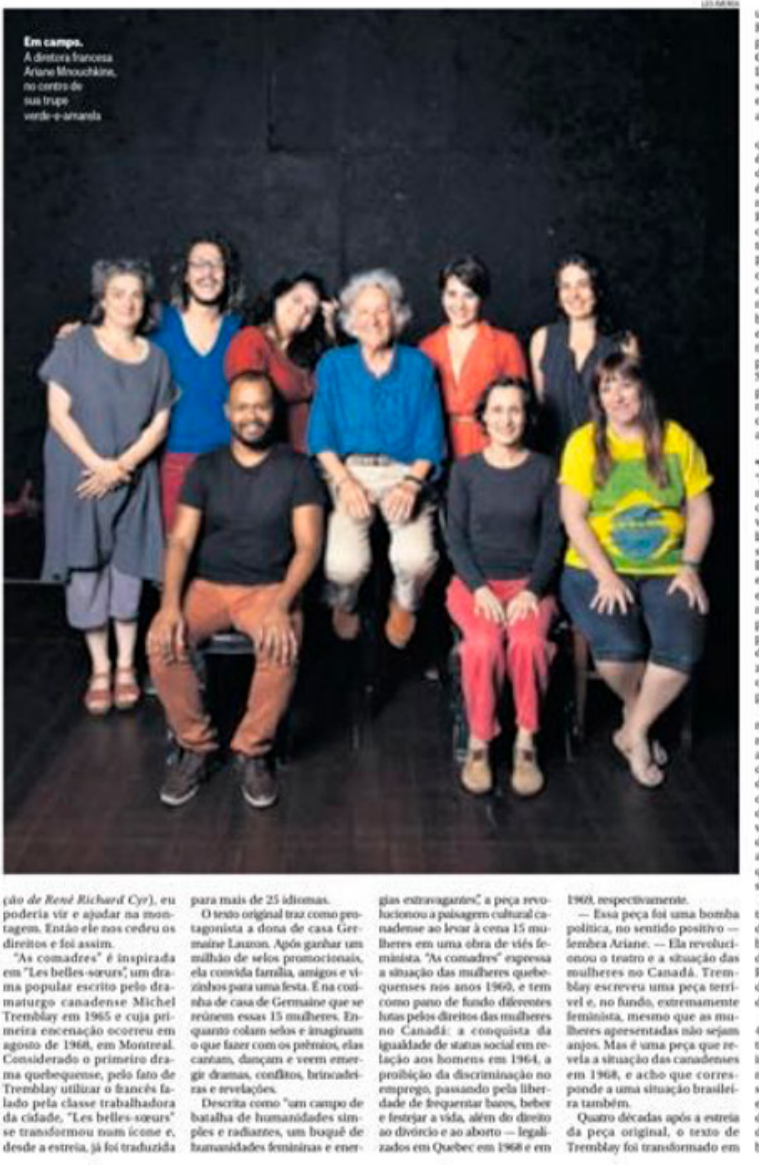

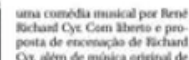

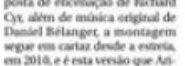

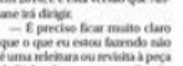

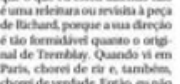

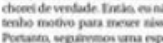

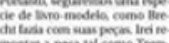

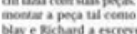

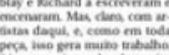





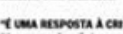

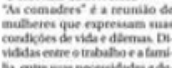

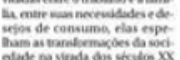

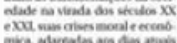

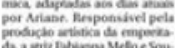

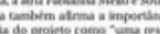



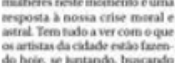

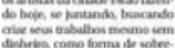

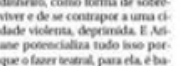

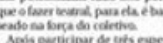

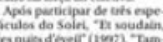
$=$

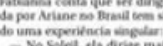

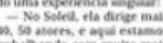
$=E=$ $=$

\begin{abstract}
"A peça foi uma bomba politica, no sentido positivo.

Revolucionou o teatro"
\end{abstract}

'Ouando vi 'As comadres' também, chorei de verdade" sem as quais não se cria um espetáculo de teatro no Brasil (e um filme documentário, sob direção da cineasta Jeanne Dosse, parceira de longa data do Soleil e filha de Juliana, multiplicando as dobras femininas do projeto) e que foram realizadas pela equipe sem nenhum tipo de remuneração prévia, apenas cicotizando o tempo e os meios que cada uma pode dispor ao projeto. Cada etapa e função foi então anotada em um diário que serviu como guia para o momento em que o projeto recebeu suas modestas remunerações, em 2019.

Estas são algumas das características do Teatro Solidário que vem sendo realizado, no sentido de apresentar uma resposta proativa e artística à escassez de meios para que o teatro (e a cultura) sobreviva no país. Mais do que isso, este foi o meio encontrado pelo grupo para subverter a lógica questionável que passou a dominar a produção teatral brasileira nas últimas décadas, em que a realização de uma

obra só se dá quando os seus meios financeiros de realização estão absolutamente garantidos via patrocínio através de leis de incentivo. Embora isso tenha fomentado o mercado teatral em um primeiro momento, contribuindo para a profissionalização dos meios de produção, percebe-se um efeito reverso que sutilmente levou o teatro brasileiro ao atual estado de impotência, para além das políticas de desmonte da cultura.

As exceções existem, tanto no teatro dito comercial quanto no teatro dito de pesquisa, mas de forma geral, é possível perceber um efeito cascata com 
consequências drásticas para o meio teatral como um todo. À medida que o sustento de um espetáculo se manteve garantido antes mesmo da realização do espetáculo durante muitos anos, a bilheteria advinda das temporadas de apresentação passou a ocupar um segundo plano na sobrevida das produções. Os compromissos de ingressos promocionais (meias entradas e convites), contrapartida social e democratização de acesso que vem a reboque das leis de incentivo (transferindo a responsabilidade social do estado e das empresas ao produtor de teatro) passaram a ocupar um número cada vez maior de cadeiras dos teatros com gratuidade e valores ínfimos e agravaram a crescente desvalorização da bilheteria como fonte de renda para as produções. Em consequência, nefasta, aos poucos se estabeleceu uma ideia de que o ingresso de teatro não tem valor financeiro, para artistas e espectadores: os convites promocionais passaram a ser supervalorizados como a moeda de intercâmbio entre essas duas instâncias essenciais para que o teatro exista. Neste cenário, a presença do público que consome teatro é cada vez menor (salvo exceções como musicais por exemplo, considerando também outros fatores que contribuem para a mudança de hábitos de entretenimento no Brasil e no mundo). E como a realização dos espetáculos prescindiu da presença do público nos últimos tempos (a produção estava paga e precisava acontecer), aos poucos estes foram se tornando herméticos, tanto pelo viés da pesquisa ensimesmada quanto pela acomodação em formas estéticas que não se comunicam mais com o indivíduo do século XXI, caminhando lentamente para uma situação dificil de reverter. Soma-se a isso o reconhecido desmonte das políticas culturais brasileiras desde 2013, na esfera federal e, nos últimos anos, também nas esferas estaduais e municipais, em diferentes níveis pelo país, levando o teatro, de forma geral (sempre salvaguardando exceções), ao impasse em que se encontra hoje, em um país dominado pelo ódio cego, flertando com o fascismo.

o Teatro Solidário de Mnouchkine veio, portanto, somar-se a uma série de novos meios de produção que surgiram pelo país como frentes de resistência ao panorama que muitos trabalhadores de teatro enfrentam, hoje: desmonte das instituições de cultura e educação, ausência do estado e das empresas como fomentadores da cultura, produções engessadas por orçamentos superfaturados de patrocínio (reflexo de um mercado inflacionado e acomodado por anos de remuneração não condicionada ao sucesso do projeto) que não encontram mais meios de captação em um país mergulhado no caos, e o que é o pior, a descrença e a indiferença de um público que afastou-se do teatro, ignora os meios de produção cultural e se submete à desorientação de agentes políticos que manipulam o senso comum, entre muitos outros fatores perversos.

Mas não é a primeira vez que Mnouchkine está envolvida na renovação dos meios de produção teatral, muito menos na realização de projetos artísticos que propõe uma reflexão política através da criação estética que subverte a ordem estabelecida, seja na França ou em outros países por onde passou, promovendo um intercâmbio de saberes através da prática de criação. Mnouchkine 
e o Théâtre du Soleil, desde o princípio de sua aventura artística nunca perderam de vista a certeza de que uma obra só se completa com o público. Seja através da criação de espetáculos de grande interação ou pela cuidadosa e delicada recepção do público em sua sede, a Cartoucherie de Vincennes, nos arredores de Paris, o público sempre se manteve em papel de destaque.

No sentido de alcançar o máximo de pessoas possível e manter acesa a chama da comunicação com o público através dos tempos, criando narrativas de múltiplas vozes, Ariane Mnouchkine e seu Théâtre du Soleil esforçam-se, há 56 anos, em dissecar a cena teatral (e cinematográfica) e construir obras que atinjam seu público imediato, nas salas de espetáculo, e possam reter a efemeridade do momento em filmes que sobrevivam através dos tempos e das plateias. A vida e obra de Ariane Mnouchkine sugerem uma praça pública, uma ágora, onde a polifonia e a multiplicidade tomam conta e o espaço comporta uma infinita sobreposição de "agoras". Chefe de trupe, ativista, diretora e cineasta, sua história é reflexo de um protagonismo que se funde ao coletivo a todo o momento.

“(...) Acontece que estamos fazendo um espetáculo que fala de instantes... Do presente que já não é presente no momento em que digo a palavra "presente". Talvez da beleza dos seres, da dificuldade que temos em apreender essa beleza, e quando, às vezes, nos damos conta do quanto esse instante era belo, ele já passou." (MNOUCHKINE: 2006, 23)

Em 1970, quando Mnouchkine e sua trupe conseguiram permissão para ocupar um dos galpões da Cartoucherie, no Bois de Vincennes, na periferia de Paris, França, para ensaiar e posteriormente apresentar o espetáculo, foi iniciada a trajetória de uma das mais bem aventuradas companhias de teatro da história.

Mas, na verdade, o início de "tudo" é ainda anterior, antecedendo até mesmo à criação da própria companhia por estudantes franceses reunidos no que chamaram de "Sociedade Cooperativa de Trabalho de Produção - Théâtre du Soleil", em 1964, visionando os movimentos estudantis e sociais que tomariam a França alguns anos mais tarde, em maio de 1968. Dos dez estudantes que fundaram esta que é uma das companhias de teatro mais antigas em atividade atualmente, duas jovens haviam criado, anos antes, em 1959, a ATEP (Associação Teatral dos Estudantes de Paris). Foram elas, a estudante da Escola do Louvre, Martine Franck, e a então estudante de psicologia, Ariane Mnouchkine. Entre as atividades da ATEP estavam a organização de cursos e conferências de teatro para estudantes - com professores das escolas de Charlles Dullin e Jacques Lecoq, por exemplo -, a recepção de companhias de teatro estrangeiras envolvidas no Teatro das Nações e a produção de espetáculos próprios. Depois de alguns anos de atividades, a ATEP foi dissolvida já que seus integrantes precisavam terminar seus estudos e prestar serviços militares, com a promessa de retomarem o projeto de criação de uma comunidade teatral, onde todos enga- 
jariam uma mesma soma em dinheiro, portando, assim, direitos e deveres iguais, e acumulando funções técnicas e administrativas às funções artísticas. Neste período de suspensão que durou dois anos, Ariane Mnouchkine partiu em uma viagem iniciática pela Ásia, onde mergulhou na arte oriental, sendo especialmente tocada pelo teatro codificado indiano e pelas máscaras japonesas.

Ao retornar à Paris, Mnouchkine retomou o grupo para a fundação efetiva do Théâtre du Soleil, que como tantos outros jovens grupos de teatro, gostariam de, nas palavras de BABLET (1979): "Fazer teatro. Mas não aquele que lhes mostravam. Não um teatro de vedetes onde se implora um cachê, onde cada um quer fazer carreira, onde cada um puxa a coberta para si. Não. Um teatro de grupo. Durante o dia, eles ganhariam a vida. À noite e na madrugada, trabalhariam juntos. Reinventariam o teatro. Foi o que fizeram." Assim, o Théâtre du Soleil, tem sua origem marcada por fatos que iluminam sua trajetória e escolha de repertório, como a vivência comunitária de todos os seus integrantes, ativismo e espetáculos com forte engajamento social voltado para a construção do bem comum, ao gosto dos princípios universais da Revolução Francesa, uma importante tendência incutida em seus processos criativos, bem como o multiculturalismo presente primeiro em seus espetáculos, depois na constituição da companhia.

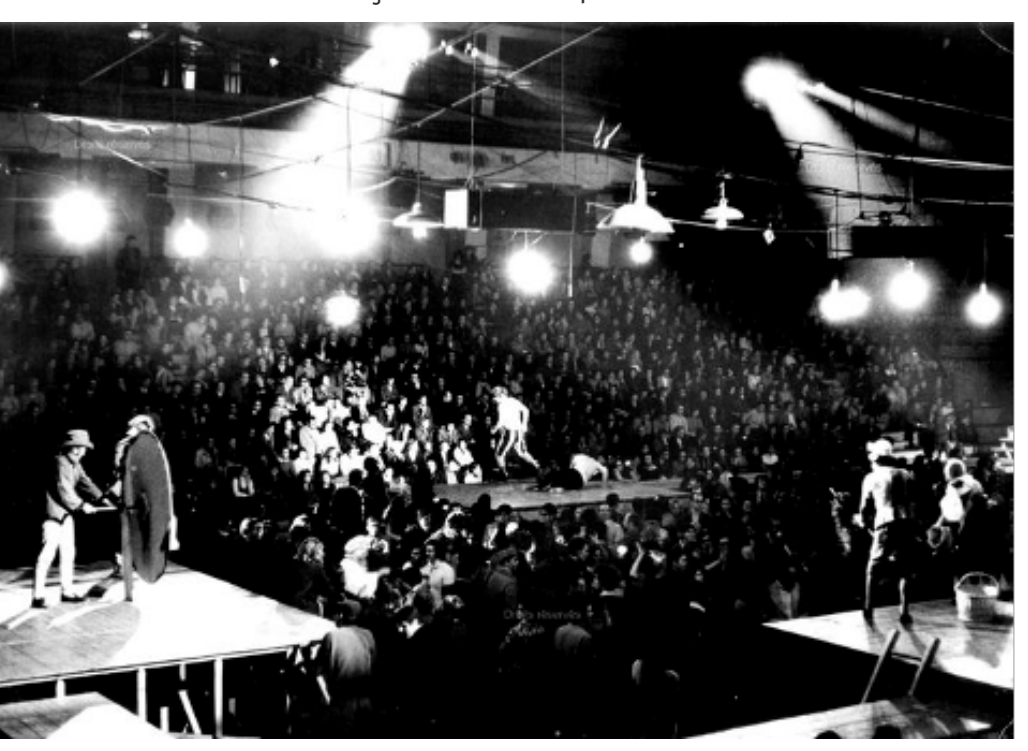

Figura 4: Imagem do espetáculo "1798 La Révolution doit s'arreter à La Perfection Du Bonheur"
É importante notar também que o surgimento de uma companhia de teatro com estes propósitos se alinha àquele momento histórico na França, com a delineação do movimento Internacional Situacionista, calcado na abolição de uma noção da arte como uma atividade especializada e segmentada, transformando-a numa ferramenta de construção da vida comum. Se para os situacionistas ou a arte era revolucionária, ou não era nada, ainda que o Théâtre du Soleil nunca tenha abdicado da formalização estética em seus espetáculos, é fato que a vivência comunitária de seus integrantes sempre caminhou para a finalidade revolucionária da arte, seja por propor meios de produção absolutamente radicais frente ao teatro comercial e de pesquisa, seja por incluir em suas atividades e espetáculos manifestações de engajamento político que muitas vezes evoluíram para o ativismo através da arte.

Por conceito e por força das circunstâncias, fundou-se, então, uma empresa coletiva, aos moldes das antigas companhias de commedia dell'arte, onde a vida comunitária e solidária foram as locomotivas para a devida ocupação 
do espaço e a manutenção do trabalho continuado dos membros da companhia, o que levou, necessariamente, à excelência artística que é a marca registrada da trupe em seus 54 anos de existência. No entanto, é interessante notar que esta excelência artística está vinculada, principalmente, à capacidade de reinvenção da própria companhia que, em escuta permanente e precisa sobre a realidade circundante, vem sendo capaz de se metamorfosear e manter acesa a chama do encontro entre o teatro e seu público. Como não poderia deixar de ser, esta capacidade de transformação se dá não só na escolha de repertório dramatúrgico e de encenação e na escuta precisa sobre a sociedade e o mundo circundante, mas principalmente, na pesquisa prática sobre o próprio espaço da encenação e do acolhimento ao público, que constitui parte essencial do processo criativo de cada espetáculo, ao gerar diferentes ambientes de afetação que contribuem para a fruição do espectador de forma específica a cada obra. Fazendo uma análise cronológica do repertório da companhia, é possivel distinguir as fases em que cada tipo de espaço cênico teve maior preponderância, sendo que a relação ator $X$ espectador proposta pelo palco italiano apresentou maior adesão durante as cinco décadas de trabalho, provavelmente por melhor se adequar ao processo de criação habitual da companhia, que muitas vezes partiu de técnicas de improvisação com máscaras teatrais de diversos gêneros e que, portanto, pressupõe a frontalidade para sua espectação.

No entanto, a partir dos anos 2000, novos caminhos de pesquisa se apresentaram à companhia, especialmente com a realização do filme "Tambours sur La Digue", o primeiro "filme de teatro" da companhia, para utilizar o termo de Beatrice Picon-Vallin (2002) que denomina filmes que se originam de espetáculos teatrais, sem que, no entanto, se perca o vínculo entre as obras. Nesta experiência, a "tradução" do espetáculo para a linguagem cinematográfica foi o gatilho pelo qual se abriram as portas de um novo universo criativo e estético no trabalho da companhia. A partir de então a escuta sobre o mundo contemporâneo passou a incluir não só as questões sociais e políticas da sociedade, mas principalmente a forma pela qual esta sociedade se expressa e se comunica. Ou seja, a companhia que sempre se deteve a uma pulsação um tanto artesanal no fazer teatral, amparada epicidade das máscaras, de repente se vê diante da necessidade de trazer à cena a velocidade e as tecnologias da comunicação que moldam o século XXI, e, principalmente, de falar com o homem que vive neste mundo. Diz Bruno Tackels em texto publicado na revista Mouvement (2007), acerca disto:

“A preocupação com o tempo presente, portanto, não é nova no Théâtre du Soleil, longe disso. Mas o que constitui a verdadeira ruptura, nos espetáculos desta década, é que a máscara está desaparecendo. Todas as formas de máscara e de sua teatralidade encontram-se guardadas na coxia, para que aqueles que fazem o espetáculo se apoiem apenas nos documentos extraídos de suas vidas, 
como se agora os atores só representassem a si mesmos, o que é sem dúvida o exercício cênico mais difícil num palco."

A teatralidade inerente aos trabalhos do Soleil precisa dar conta também deste universo em ebulição e será através das técnicas de cinema que a pesquisa da companhia passa a se encaminhar por outras trilhas, atingindo resultados como a qualidade performativa no trabalho dos atores que se evidencia. É neste sentido que se percebe nos espetáculos que sucedem Tambours sur la Digue, as características pelas quais o teatro ganha contornos de performance na concepção de Josette Féral, a saber

“... transformação do ator em performer, descrição dos acontecimentos da ação cênica em detrimento da representação ou de um jogo de ilusão, espetáculo centrado na imagem e na ação e não mais sobre o texto, apelo a uma receptividade do espectador de natureza essencialmente especular ou aos modos das percepções próprias da tecnologia." (FÉRAL: 2015, 114).

Importa ressaltar que o cinema sempre esteve implicado nas criações do Soleil, não só como registro e versões dos espetáculos, mas, principalmente, como instrumental de construção da encenação. Utilizando a ideia de cineficação, também proposta por Picon-Vallin (2011), que consiste na apropriação pelo teatro de alguns elementos do cinema, é possível verificar ao longo dos trabalhos da companhia, a co-existência das duas vertentes expostas pela autora: a externa, caracterizada pela utilização das tecnologias de projeção e captação de imagens no espaço teatral, e a interna, que implica na utilização das técnicas cinematográficas para a construção da cena. Não por acaso, a disciplina pedagógica de base da companhia é o jogo das máscaras, que disparam estruturas narrativas simples e diretas, presentes também nos filmes do "primeiro cinema", na denominação de Jacques Aumont, que compreende o período que vai das primeiras experiências dos irmãos Lumière até a introdução do cinema sonoro. Lembrando que, por sua vez, estes filmes são a própria transposição do teatro da época para a nova mídia que se apresentava, se vê uma sobreposição de referências, onde o teatro e o cinema perdem suas fronteiras.

E foi nesta sobreposição de referências e ins-

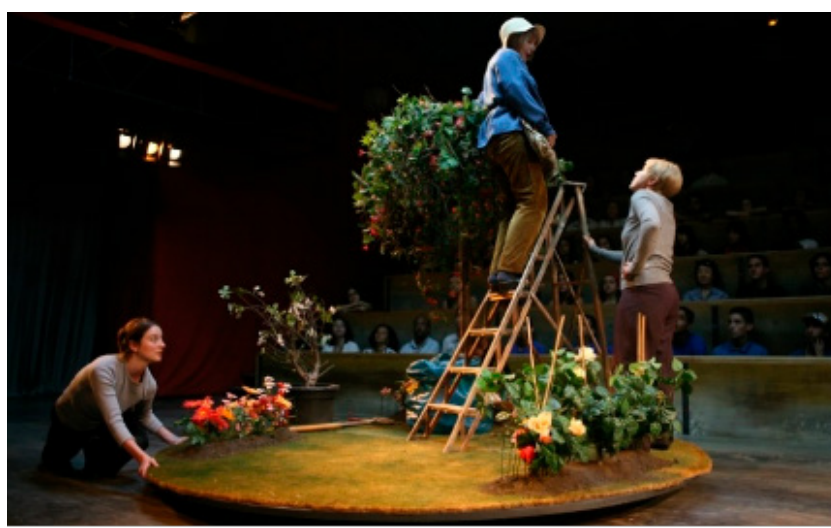

Figura 5: Imagem do espetáculo "Les Éphémères" (2005) pirações artísticas que o Théâtre du Soleil desenvolveu seu repertório de espetáculos que guardam, ao mesmo tempo, a dedicação e a paixão pelo teatro artesanal, de pesquisa, laboratorial, e o esquema quase industrial que gerencia uma empresa criativa que envolve, atualmente, mais de 70 pessoas entre 
artistas, técnicos e pessoal de escritório, e que já se apresentou em todos os continentes. Vê-se, uma vez mais, nesta dualidade, as vocações pelo teatro e pelo cinema caminhando de mãos dadas e, mais uma vez, é o espaço da Cartoucherie, com seus vários galpões para usos diversos onde a companhia permanece sediada que permite esta comunhão de linguagens, tornando sempre profícua a criação de cada espetáculo, de cada filme e garantindo a renovação de suas plateias.

Como seria, então, o encontro de Mnouchkine, depois de décadas à frente de uma empreitada como o Théâtre du Soleil, com tudo o que ela representa para o teatro e para o cinema francês dos séculos XX e XXI, com um grupo de atrizes não muito familiarizadas com toda essa prática, no Rio de Janeiro, no contexto atual brasileiro, para a criação de uma comédia musical a partir do musical original canadense (que é em si uma revisitação à peça de 1968)? Essa é uma pergunta concreta, que inquietou e ainda inquieta a todos os envolvidos em As Comadres, especialmente a própria Mnouchkine que, em sua maestria e humildade, se reinventou diante da total novidade do projeto. A proposta foi partir da encenação de Cyr, copiando cenário, partituras físicas e vocais das atrizes, em um sistema "mestre-aprendiz" possível pela existência do registro fílmico do espetáculo canadense. Os desafios e surpresas que essa metodolo-

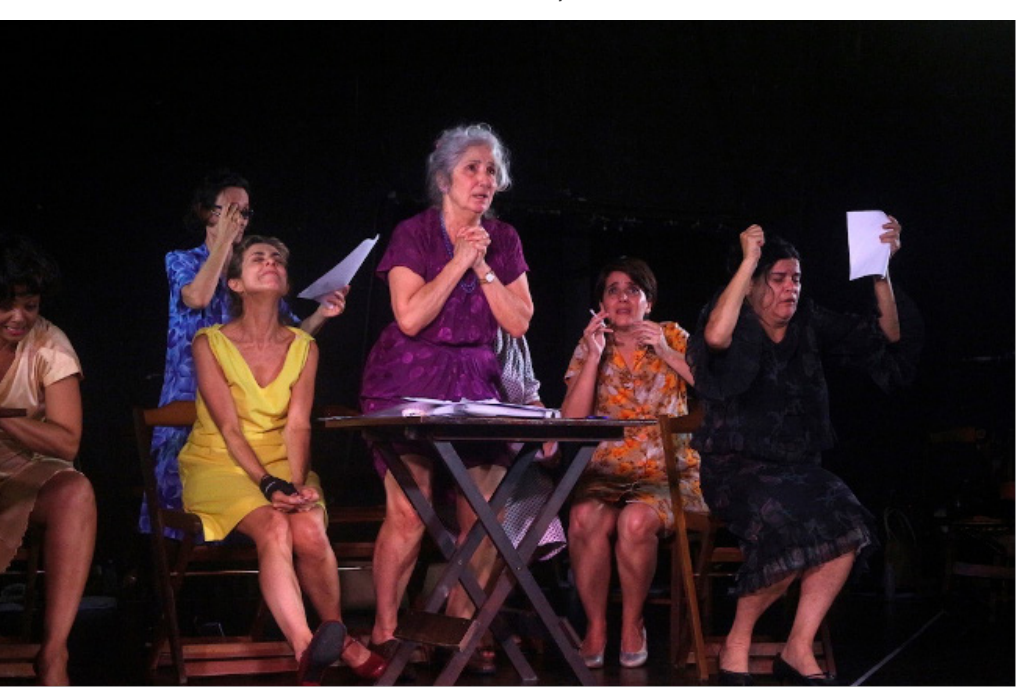

Figura 6: Foto de Pedro de Andrade dos ensaios do espetáculo As Comadres (2018) gia apresentou rendem um outro artigo, para um outro momento...

O primeiro encontro com o grupo completo, em junho de 2018, deu-se em uma harmonia construída passo a passo por cada um dos integrantes do grupo. No palco do Teatro Sérgio Porto no Rio de Janeiro, havia um cenário de ensaio montado, algumas araras de figurinos e adereços, um piano, partituras, letras de músicas e textos à disposição de um grupo de atrizes e artistas igualmente disponíveis para a aventura que se concretizava naquele momento. Mnouchkine conduziu três semanas de experimentações surgidas do encontro entre a sua metodologia, o texto quebequense e artistas brasileiros, cujos resultados ainda estão em ebulição. Fazer a transposição do texto de Cyr (2010), ainda impregnado pelas questões políticas do Quebec de 1968 que incitaram Tremblay, para a embocadura de atrizes brasileiras de 2018 foi o principal dispositivo de criação do espetáculo.

As questões não pararam de brotar: até que ponto o Quebec do espetáculo seria hermético para o público brasileiro? O que seria o equivalente ao joual na língua portuguesa? Existe um português brasileiro? A simples criação do

Revista do Laboratório de Dramaturgia | LADI - UnB Vol. 14, Ano 5 | Dossiê música e cena do Théâtre du Soleil 
espetáculo por brasileiras já não é adaptação suficiente? Como estabelecer um elenco de um musical seguindo os princípios da evidência e da alternância praticado no Soleil? Até que ponto irá a verossimilhança entre as atrizes canadenses e as brasileiras, posto que se trabalha no método "mestre-aprendiz" a partir de um filme? É imprescindivel que a proporção de atrizes negras no elenco brasileiro seja a mesma que da população brasileira! Mas havia negras no Quebec de 1968? Temos que garantir que a mulher brasileira esteja representada em toda a sua multiplicidade no espetáculo! Quem é a mulher da periferia no Brasil na década de sessenta? E hoje em dia? Quem é a mulher brasileira hoje? Quem são as mulheres brasileiras hoje? E as trans? Ficarão de fora do espetáculo? Quem seriam as trans quebequenses? E as brasileiras? E a lesbiandade que surge no espetáculo? Retiraremos seu véu ou não? E como fica o filtro do olhar estrangeiro entre todas essas variantes? E como nós, artistas, hoje, de tantas gerações diferentes, damos conta dessas questões tão próximas porque femininas, tão femininas porque dolorosas, tão dolorosas por-

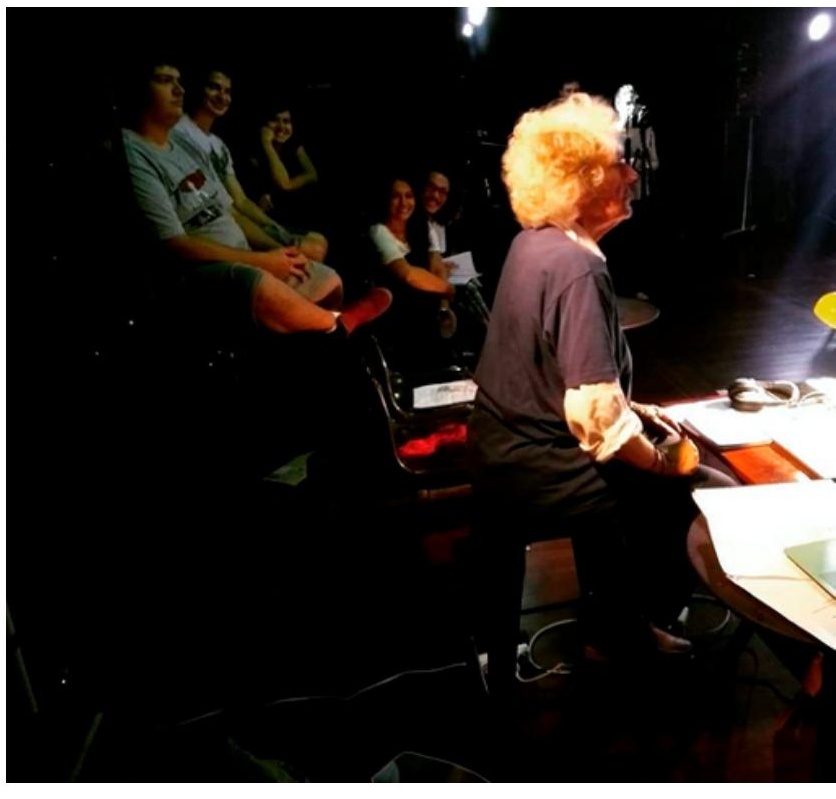

Figura 7: Foto de Pedro de Andrade dos ensaios do espetáculo As Comadres (2018) que brasileiras?

Assim como no Soleil, onde o tempo é tido como o bem mais valioso na criação de suas obras (cênicas e fílmicas), no processo de As Comadres (espetáculo e documentário), essas e outras questões foram decantadas ao sabor do tempo que insistiu em passar mais rápido do que deveria nos trópicos de

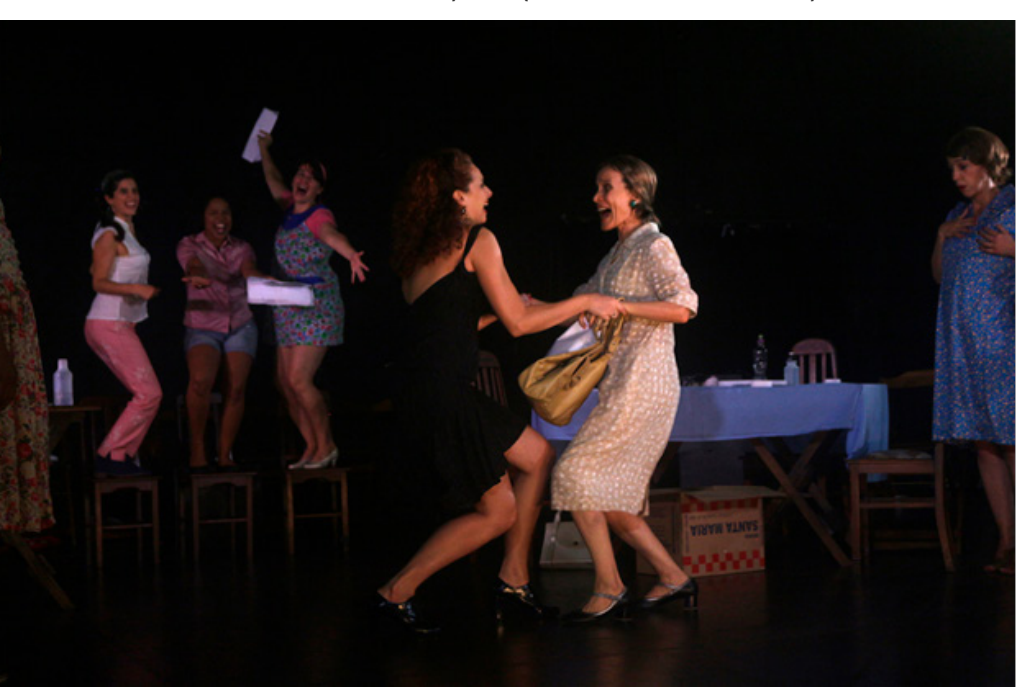

Figura 8: Foto de Pedro de Andrade dos ensaios do espetáculo As Comadres (2018) cá. Como se as urgências brasileiras parecessem mais urgentes. No último dia de ensaio da primeira etapa, que coincidiu com o último jogo do Brasil na Copa do Mundo, toda a equipe promoveu um almoço de confraternização regado a caipirinhas, convidando maridos, esposas, companheiros, companheiras, filhos e filhas, mães e pais. Nos permitimos acompanhar os dissabores do futebol brasileiro, cantar e dançar outros ritmos menos nórdicos, confabular, rir de nós mesmos, chorar de felicidade e da saudade que já começava a se aninhar, planejar os passos futuros, alinhar as expectativas frente 
às incertezas da realidade que surpreende mesmo os melhores autores do teatro do absurdo e, principalmente, celebrar o feminino como uma das vias de resistência e transformação do mundo pelo teatro.

Os resultados dessa aventura desdobraram-se no espetáculo que foi visto por 15.000 espectadores no Brasil e em 2021 fará turnê pela França e, se os deuses do tetro permitirem, também por Portugal. Será uma festa de "colação de selos"!

\section{Bibliografia}

AUMONT, Jacques. O Cinema e a Encenação. Lisboa: Texto \& Grafia, Ltda. 2006

COSTA, Flávia Cesarino. O primeiro cinema - Espetáculo, narração, domesticação. Rio de Janeiro: Azougue Editorial, 2005.

FÉRAL, Josette. Além dos limites - Teoria e prática do teatro. São Paulo: Perspectiva. 2015

FÉRAL, Josette. Trajectoires du Soleil: Autour d'Ariane Mnouchkine. Paris: Éditions Theatrales, 1998.

Dresser un monument à l'éphémère: rencontres avec Ariane Mnouchkine. Paris: Éditions Theatrales, 1995.

GERMAINE, Jean Claude. J'ai eu le coup de foudre. In Théâtre Vivant. Montréal: Holt, Rinehart et Winston limitée, 1968.

MILLER, Judith G. Ariane Mnouchkine. New York: Routledge, 2007.

PASCAUD, Fabienne. L'art du present. Paris: Plon, 2005.

PICCON-VALLIN, Béatrice. Ariane Mnouchkine. Paris: Actes Sud, 2009.

PICON-VALLIN, Beatrice, Le Théâtre du Soleil . Les cinquante premières années, Actes Sud. Actes Sud, 352 p. 313 images, 2014, Hors collection

TACKELS Bruno, Les mobiles du Soleil, Mouvement, 1er avril 2007

VACCARI, Eduardo Ferreira Chaves. Encenar ensinando - Ensinar encenando: a relação entre encenação e pedagogia a partir da análise de processos de criação do Thèâtre du Soleil / Teses UniRio 2014. ed. 


\section{Filmes}

DARMOND, Eric; VILPOUX, Catherine. Au soleil même la nuit. Coproduction AGAT Film \& Cie, La sept ARTE, Le Théâtre du Soleil. DVD, cor., 190 min., 2011.

MNOUCHKINE, Ariane. 1789. VHS, cor, $120 \mathrm{~min}$.

Tambours sour la digue. Bel Air Media, Théâtre du Soleil, ARTE France, CNDP, ZDF Theatrekanal. DVD, cor., 158 min., 2002.

Molière. BEL AIR Classiques et CNDP. DVD, cor, 244min., 2004.

Le Dernier Caravansérail (Odyssées). BEL AIR Classiques, ARTE

France et CNDP. DVD, cor, 305min., 2006.

Les Éphémères. BEL AIR Classiques, ARTE France et CNDP. DVD, cor, 347min., 2009.

VANNUCCI, Duccio Bellugi; SABIDO, Sergio Canto; CHEVALIER, Philippe. Un Soleil à Kaboul. Bel Air Media, Thèâtre du Soleil, Bell Canto Laï. DVD, cor., 75 min., 2007.

VILPOUX, Catherine. Ariane Mnouchkine: l'aventure du Théâtre du Soleil. AGAT Film \& Cie, ARTE France, Le Théâtre du Soleil, INA, Bel Air Média. DVD, cor, 75 $\min , 2009$. 